\title{
Annealing effect of hybrid solar cells based on poly (3- hexylthiophene) and zinc-oxide nanostructures
}

\author{
David E. Motaung, Gerald F. Malgas, Suprakas S. Ray and Christopher J. Arendse
}

\begin{abstract}
:
The structural growth and optical and photovoltaic properties of the organic-inorganic hybrid structures of zinc oxide ( $\mathrm{ZnO})$-nanorods/poly-3-hexylthiophene $\left(\mathrm{P}_{3} \mathrm{HT}\right)$ and two variations of organic polymer blends of $\mathrm{ZnO} / \mathrm{P}_{3} \mathrm{HT}: \mathrm{C} 60$ fullerene and $\left.\mathrm{ZnO} / \mathrm{P}_{3} \mathrm{HT}: 6,6\right]-$ phenyl $\mathrm{C} 61$ butyric acid methyl ester were studied in detail during thermal annealing. The ordering of the $\mathrm{P}_{3} \mathrm{HT}$ nanocrystals increased during annealing, which also improved hole transport in the hybrid structures. The optical constants of the $\mathrm{ZnO} / \mathrm{P}_{3} \mathrm{HT}$ :[6,6]-phenyl C61 butyric acid methyl ester (PCBM) films elevated with annealing temperature due to the improved crystallisation induced by the formation of $\mathrm{P}_{3} \mathrm{HT}$ crystalline domains. As a result, a maximum power conversion efficiency of approximately $1.03 \%$ was achieved for the annealed $\mathrm{ZnO} / \mathrm{P}_{3} \mathrm{HT}: \mathrm{PCBM}$ device at $140{ }^{\circ} \mathrm{C}$. These findings indicate that $\mathrm{ZnO}-$ nanorods/P3HT:PCBM films are stable at temperatures up to $160{ }^{\circ} \mathrm{C}$.
\end{abstract}

\section{Introduction}

Since the discovery of their electroluminescence [1], conjugated polymers have been extensively studied for a wide range of opto-electronic applications such as polymer light emitting diodes [2] and organic photovoltaic devices [3]. The advantage of conjugated polymers over other electronic materials is that they can be readily processed into thin films from solution using techniques such as spincoating or inkjet printing [4], thereby offering the prospect of low cost manufacturing processes. However, the morphology of a bulk heterojunction consisting of a binary blend cannot be easily controlled. The formation of the final blended structure is affected by several parameters, such as the blend composition, viscosity, solvent evaporation rate [5] and substrate surface energy, all of which present difficulties in the achievement of the desired blend morphology for maximum charge generation and transport [6].

A promising power conversion efficiency of up to $5 \%[7,8]$ has been reported using regioregular poly (3-hexylthiophene) ( $\mathrm{P}_{3} \mathrm{HT}$ ) and (6,6)-phenyl $\mathrm{C}_{61}$ butyric acid methyl ester (PCBM) as the electron donor and the electron acceptor materials, respectively. This result was achieved through optimisation of the morphology by various treatments, such as thermal annealing [9-12], solvent annealing [13,14], substrate annealing [15] or the use of additives $[16,17]$, which can lead to a molecular rearrangement of the spin-coated film. Metal oxide nanostructures, such as titanium dioxide $\left(\mathrm{TiO}_{2}\right)$ [18,19], zinc oxide ( $\left.\mathrm{ZnO}\right)$ [20-23], and tin dioxide $\left(\mathrm{SnO}_{2}\right)$ [24], possess unique properties such as high conductivity, mobility and good stability in comparison with their PCBM counterpart. However, no conclusive work 
has been conducted to optimise the morphology of both metal oxides such as $\mathrm{ZnO}$ and the PCBM incorporated in $\mathrm{P}_{3} \mathrm{HT}$ through annealing at various temperatures. Therefore, in this work, X-ray diffraction (XRD), ultraviolet-visible spectroscopy (UV-vis) and variable angle spectroscopic ellipsometry (VASE) are used to identify the evolution of the structure, morphology and optical properties of $\mathrm{ZnO}$-nanorods/ $\mathrm{P}_{3} \mathrm{HT}$ and $\mathrm{ZnO}-$ nanorods/P3HT:fullerenes at different annealing temperatures. These findings are also correlated with device performance.

\section{Experiment details}

\subsection{Materials and chemicals}

Regioregular poly(3-hexylthiophene) (rr-P3HT) polymer (molecular weight $~ 64,000$ gmol $^{-1}$; regioregularity > 98.5\% for head-to-tail), buckminsterfullerene-C6o (99.5\% purity grade), PCBM (99.5\% purity grade), zinc nitrate, potassium hydroxide (KOH), indium tin oxide (ITO) (coated on a $1 \mathrm{~mm}$ glass substrate (surface resistivity 8-12 $\Omega / \mathrm{sq}^{-1}$ ) ) and chloroform (anhydrous, $\geq 99 \%$ ) solution were purchased from SigmaAldrich and silicon ( $\mathrm{Si}$ ) (100) with resistivity of $1-30 \Omega / \mathrm{cm}$, thickness of $375 \pm 25 \mu \mathrm{m}$, was purchased from Semiconductor Wafer, Inc. All chemicals were used as received without any purification.

\subsection{Synthesis of zinc oxide-nanorods}

Zinc oxide ( $\mathrm{ZnO}$ )-nanorods were prepared by dissolving approximately $4.8 \mathrm{~g}$ of zinc nitrate and $4 \mathrm{~g}$ of $\mathrm{KOH}$ in $50 \mathrm{ml}$ of deionised water. The resultant mixture was then transferred to a $100 \mathrm{ml}$ Teflon liner and placed in a microwave reactor (Multiwave 3000 ) at $180{ }^{\circ} \mathrm{C}$ for 20 min. Afterwards, the resultant mixture was collected by filtration and washed repeatedly in deionised water and alcohol in an ultrasonic bath to remove nitrate and potassium and to minimise particle agglomeration. The final product was dried overnight in an oven at $80{ }^{\circ} \mathrm{C}$ to obtain ZnO-nanorods.

\subsection{Sample preparation and characterisation}

Indium tin oxide (ITO)-coated glass and silicon ( $\mathrm{Si}$ ) substrates were successively cleaned with organic solvents. Photoactive layers of $\mathrm{P}_{3} \mathrm{HT}, \mathrm{P}_{3} \mathrm{HT}$ :C6o or $\mathrm{P}_{3} \mathrm{HT}$ :PCBM (1:1 wt. ratio) with a thickness of approximately 90-110 $\mathrm{nm}$ were spin-coated from a $1 \mathrm{ml}$ chloroform solution on top of the ITO-glass and Si substrate at $2000 \mathrm{rpm}$ for $30 \mathrm{~s}$. A $200 \mathrm{~nm}$ layer of $\mathrm{ZnO}$ was then spin-coated from chloroform (anhydrous, $299 \%$ ) solution on top of the blended structures at a spinning rate of $3000 \mathrm{rpm}$ for $30 \mathrm{~s}$ to form $\mathrm{ZnO} / \mathrm{P}_{3} \mathrm{HT}$, $\mathrm{ZnO} / \mathrm{P}_{3} \mathrm{HT}: \mathrm{C}_{60}$ and $\mathrm{ZnO} / \mathrm{P}_{3} \mathrm{HT}: \mathrm{PCBM}$ bilayers. The structures were subjected to a thermal annealing process $\left(80-220^{\circ} \mathrm{C}\right)$ for $15 \mathrm{~min}$. 

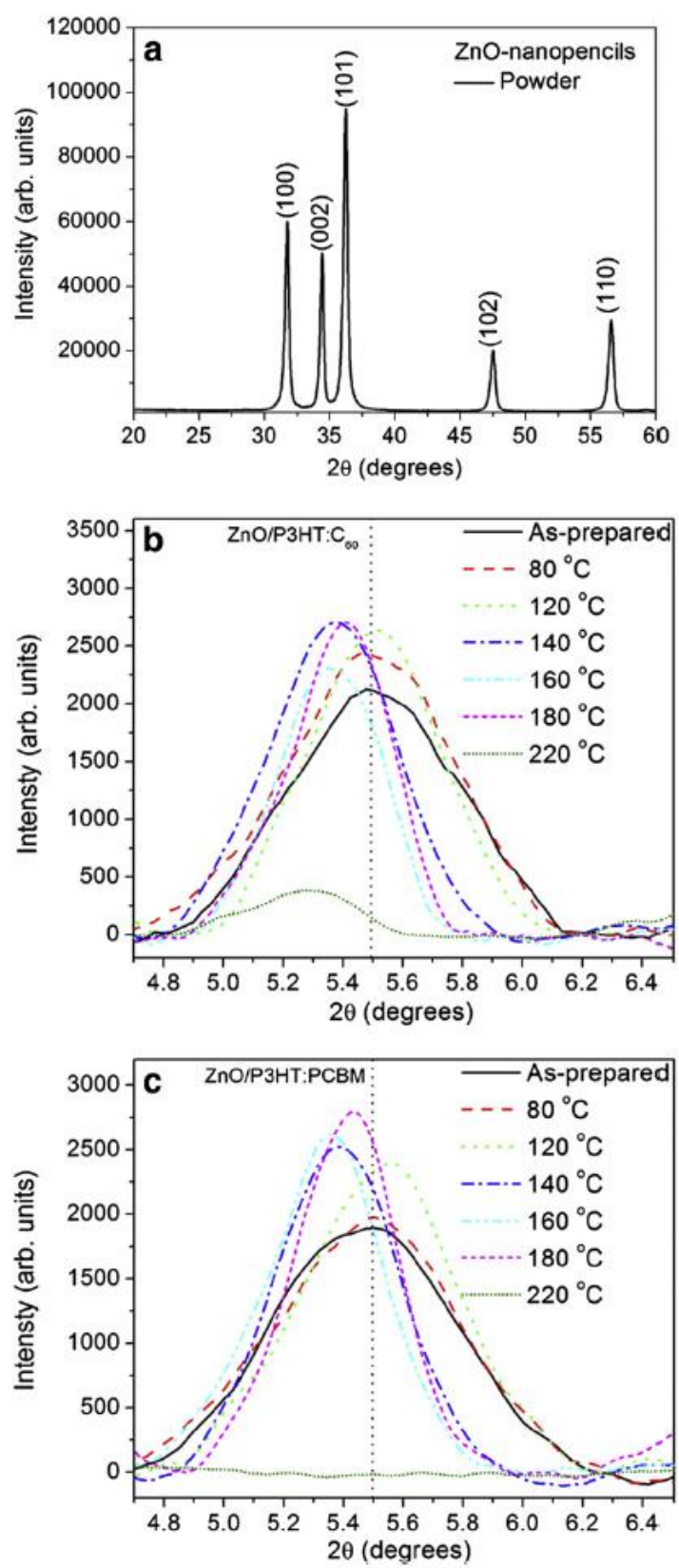

Fig. 1. XRD patterns of the as-prepared (a) ZnO-nanorods, (b) $\mathrm{ZnO} / \mathrm{P3} \mathrm{HT}: \mathrm{C}_{60}$, and (c) $\mathrm{ZnO} / \mathrm{P3HT}$ : $\mathrm{PCBM}$ structures compared to those annealed at temperatures ranging from 80 to $220^{\circ} \mathrm{C}$ for $15 \mathrm{~min}$, with an increment of $20^{\circ} \mathrm{C}$; and (d) cross-sectional SEM image of $\mathrm{ZnO} / \mathrm{P3HT}: \mathrm{PCBM}$ annealed at $220^{\circ} \mathrm{C}$.

The surface morphology of $\mathrm{ZnO}$-nanorods was obtained using a scanning electron microscope (JEOL - JSM $7500 \mathrm{HR}-\mathrm{SEM}$ ) operated at an accelerating voltage of $2 \mathrm{keV}$. Atomic force microscopy (AFM) images of the thin films spin-coated on top of the Si substrates were analysed using a Veeco AFM system (Digital Instruments) at ambient conditions in tapping mode. The structural properties of the ZnO-nanorods/P3HT:PCBM films spin-coated on Si substrates were investigated using a PANalytical X'Pert PRO PW 3040/60 X-ray diffractometer with a $\mathrm{Cu} \mathrm{Ka} \quad(\lambda=0.154 \mathrm{~nm})$ monochromated radiation source. X-ray diffraction (XRD) patterns were collected using $2 \theta$ reflection geometry, operating at $45 \mathrm{kV}$ and $40 \mathrm{~mA}$. The XRD patterns were collected at $2 \theta$-values ranging from 1 to $90^{\circ}$, with a step size of $0.02^{\circ}$. To measure the crystal sizes, background subtraction was performed on the XRD data using either a Gaussian fit or the PANalytical X'Pert HighScore Plus software, which was installed to analyse the XRD results. To determine the ultraviolet (UV)-visible absorption, films were spin-coated on top of ITO-glass and measured using a Perkin-Elmer Lambda 750 
UV-vis spectroscope. Photoluminescence (PL) spectra were carried out using and JobinYvon NanoLog spectrometer. The emission was detected with a Jobin-Yvon PMT detector. It should be noted that for photoluminescence measurements, the structures deposited onto $\mathrm{Si}$ substrates were used. The variable angle spectroscopic ellipsometry (VASE) spectra ( $\Psi$ ) and $(\Delta)$ were obtained in the range of $250-1000 \mathrm{~nm}$ at room temperature using a rotatingcompensator instrument (J.A. Woollam, M-2000) at multiple angles of incidence $(65,70$ and $75^{\circ}$ ). For data analysis, thin films spin-coated on ITO-glass substrates were regarded as homogeneous materials with film thicknesses modelled using the Cauchy model [25]. A $B$ Spline model [26] was then used to extract the refractive index (n) and extinction coefficient (k) over the absorption range from 300 to $900 \mathrm{~nm}$. The thicknesses of the films at different temperatures were extracted using VASE.

Solar cells were completed by laminating a platinum top electrode on top of an ITO glass substrate. This glass/Pt substrate was placed on top of the ITO/poly (3,4ethylenedioxythiophene):poly(styrenesulfonate)/ZnO/P3HT:fullerene substrate at an appropriate displacement and then laminated together by applying pressure at a controlled temperature using a hydrostatic pressuriser with hot plates (AH-1TC, ASONE, Japan) [27]. Current density-voltage $(\mathrm{J}-\mathrm{V})$ characteristics were measured using a Keithley 4200 Semiconductor Characterization System and a solar simulator equipped with a xenon short arc lamp-based Sciencetech SF150 with $150 \mathrm{~W}$ of power and an AM $1.5 \mathrm{G}$ solar filter. Light was irradiated from the ITO/glass side. The effective area of the solar cells was measured to be $0.45 \mathrm{~cm}^{2}$. All of the photovoltaic measurements were evaluated in air at room temperature.

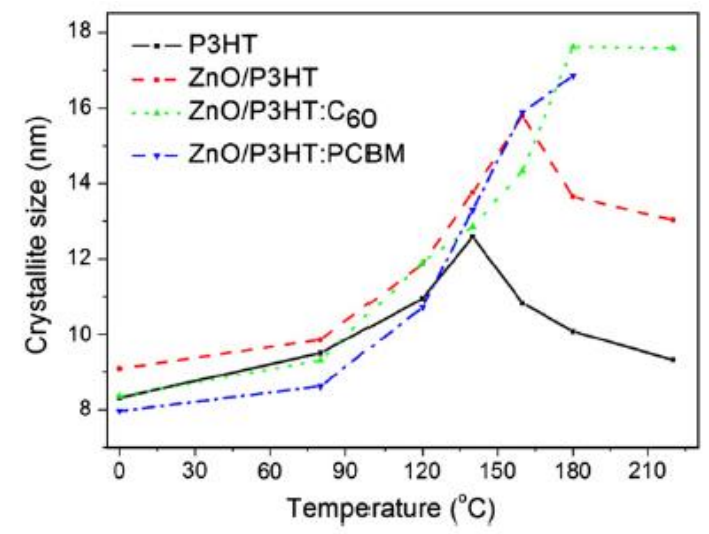

Fig. 2. Evolution of the average P3HT (100) crystallite size with annealing temperatures ranging from 80 to $220^{\circ} \mathrm{C}$ for $15 \mathrm{~min}$, with an increment of $20^{\circ} \mathrm{C}$

\section{Results and discussion}

Scanning electron microscopy (SEM) micrographs of the synthesised $\mathrm{ZnO}$-nanorods illustrate that the material has a "flower-like" morphology (results not shown). The SEM analysis showed that the $\mathrm{ZnO}$-nanorods are joined together at one end (head or seed) to form the centre, and each nanorod then grows out from the centre, similar to a flower. Each $\mathrm{ZnO}-$ nanorod array consists of a hexagonal stem with a tapering tip pref- erentially grown along the c-axis direction with an average diameter and length in the range of $300-450 \mathrm{~nm}$ and $1-2 \mu \mathrm{m}$, respectively. The growth mechanism of these structures was explained in detail by Phuruangrat et al. [28]. 
The diffraction peaks in Fig. 1a confirm the formation of pure hexag- onal wurtzite type [29] ZnO-nanorods, illustrating that the synthesised $\mathrm{ZnO}$-nanorods have good crystallinity and are highly pure. The ob- served strong diffraction peaks of the (101) and (100) suggest that the b101> and b10o> are the main preferred growth orientations for the $\mathrm{ZnO}$ nanorods. It was observed from high resolution transmission electron microscopy and the corresponding selected area electron diffrac- tion study that the as-prepared $\mathrm{ZnO}$ nanostructures are single-crystalline and that the $\mathrm{ZnO}$ nanorods have a wurtzite structure with a growth direc- tion along the c-axis [30,31]. The $\mathrm{ZnO}$ nanocrystallite sizes along the b100> and b101> orientation, estimated from the Debye-Scherrer formula [32], are 24.38 \pm $0.008 \mathrm{~nm}$ and $23.26 \pm 0.017 \mathrm{~nm}$, respective- ly. The XRD patterns of the $\mathrm{ZnO} / \mathrm{P}_{3} \mathrm{HT}: \mathrm{C}_{60}$ and $\mathrm{ZnO} / \mathrm{P}_{3} \mathrm{HT}$ :PCBM structures reveal substantial intensity alteration with thermal annealing (see Fig. $1 \mathrm{~b}$ and c). The intensity of the characteristic peak around $2 \theta=5.41^{\circ}$, which is assigned to the reflections of crystallographic (100) planes of the P3HT crystals [33,34], is enhanced abruptly with an increase in annealing tem- perature. This enhancement represents an improvement in the degree of crystallisation of the $\mathrm{P}_{3} \mathrm{HT}$ domains that was induced by annealing.

With an increase in temperature close to the crystallisation tem- perature $\left(180^{\circ} \mathrm{C}\right)$ of $\mathrm{P}_{3} \mathrm{HT}$ [35], the (100) reflections shift to higher $2 \theta$ values, indicating a contraction in the length of the alkyl-chains, and are accompanied by an increase in peak intensity [15]. Annealing above the crystallisation temperature of $\mathrm{P}_{3} \mathrm{HT}$ results in a shift of the (100) peak towards lower $2 \theta$ values, indicating an increase in the lattice spacing up to the melting temperature [15,35]. Statistical analysis of the peak profile reveals growth in the $\mathrm{P}_{3} \mathrm{HT}$ crystallite size (Fig. 2) with the annealing temperature $\left(80-140{ }^{\circ} \mathrm{C}\right.$ ) for pure $\mathrm{P}_{3} \mathrm{HT}$. When $\mathrm{ZnO}$ is spin-coated on top of the $\mathrm{P}_{3} \mathrm{HT}$ layer, the crystallites increase in size up to a temperature of $160{ }^{\circ} \mathrm{C}$. At temperatures above the crystallisation temperature, the crystallite sizes (Fig. 2) of $\mathrm{P}_{3} \mathrm{HT}$ are reduced drastically due to disordering of the polymer chains, which is induced by melting and the diffusion of the PCBM molecules. This finding is confirmed by the cross-sectional SEM images in Fig. 3a, where the "skin layer" of the polymer peels off, resulting in folding (see arrows) on the polymer "skin layer" that covers the PCBM clusters and the $\mathrm{ZnO}$ layer upon annealing at $220{ }^{\circ} \mathrm{C}$. At this temperature, the film thickness reduces due to the melt- ing of the polymer. 

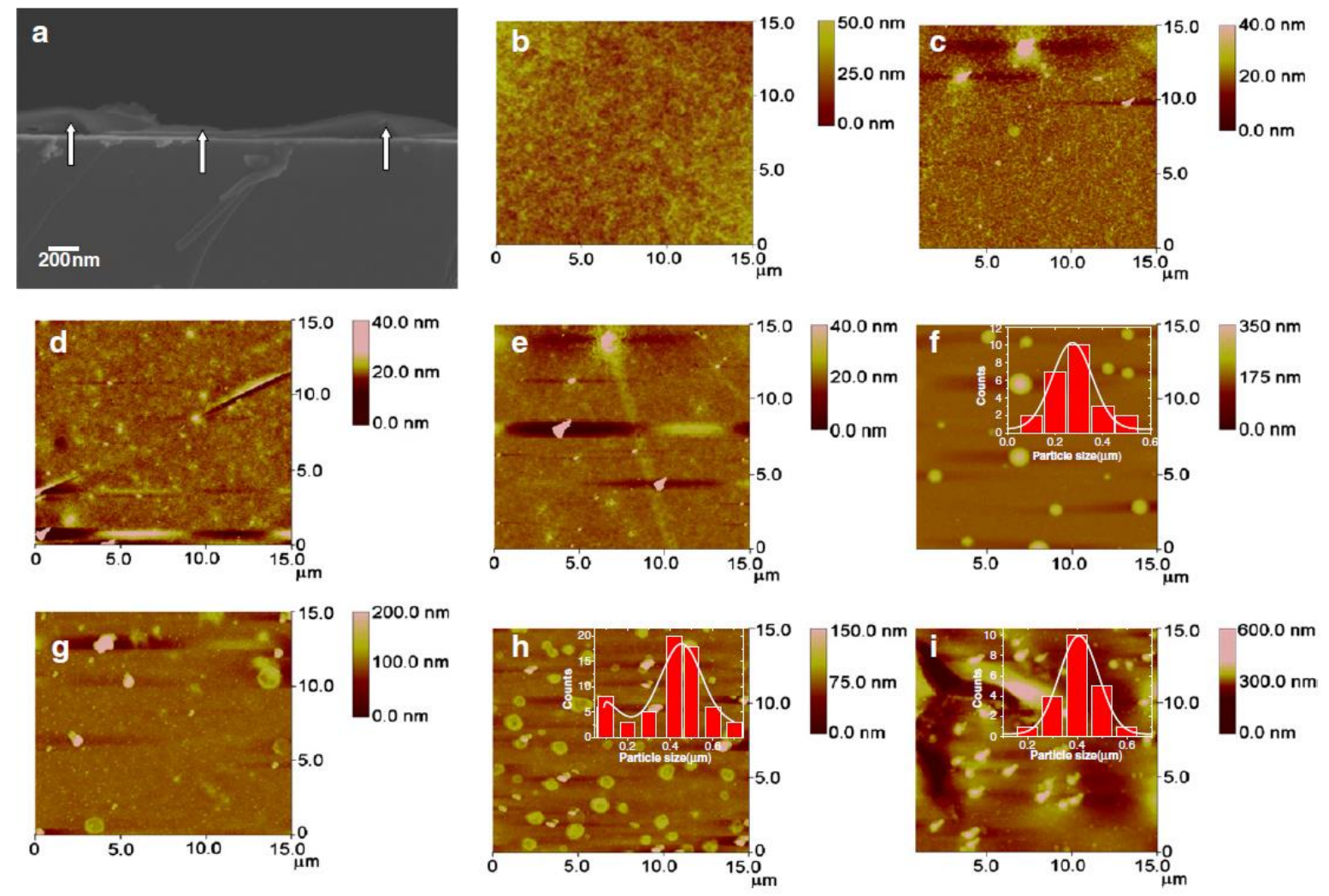

Fig. 3. (a) Cross-sectional SEM micrograph of ZnO/P3HT:PCBM annealed at $220^{\circ} \mathrm{C}$, (b-e) AFM height images of the as-prepared P3HT and annealed film, and (f-i) AFM height images of the as-prepared and annealed $\mathrm{ZnO} / \mathrm{P3HT}$ hybrid structures. The insets in $\mathrm{f}, \mathrm{h}$ and $\mathrm{i}$ correspond to the particle size distribution.

Morphology control of the active layer in bulk hetero junction devices is essential for obtaining high energy conversion efficiency. To probe the surface morphology of the polymer and the bilayer films, AFM measure- ments were performed. The attractive differences in the phase segrega- tion between the polymer and bilayer films are depicted in Fig. 3b-i. It is evident that the as-prepared $\mathrm{P}_{3} \mathrm{HT}$ film has a smooth surface with a surface roughness of approximately $4.73 \mathrm{~nm}$. However, when the P3HT film is annealed at temperatures between 80 and $160{ }^{\circ} \mathrm{C}$ (for $15 \mathrm{~min}$ ), possible growth of "fibrillar-like" structures across the film surface is observed, Fig. $3 \mathrm{c}-\mathrm{d}$. It is interesting to note that after annealing the film at $220{ }^{\circ} \mathrm{C}$, the size of the "fibrillar-like" structures decreases, and the film becomes flatter and smoother, as shown in Fig. 3e.

When $\mathrm{ZnO}$-nanostructures are incorporated onto the $\mathrm{P}_{3} \mathrm{HT}$ surface, "cone-like" structures are observed across the film, as shown in Fig. 3f. The average size of these cones is $\sim 280$ $\mathrm{nm}(0.28 \mu \mathrm{m})$ as depicted in Fig. 3 f, inset. It is believed that these $\mathrm{ZnO}$-structures act as direct carrier transport pathways to the ITO electrode, thus reducing charge recombination. Moreover, an increase in the surface roughness of approxi- mately $9.21 \mathrm{~nm}$ is observed for the $\mathrm{ZnO} / \mathrm{P}_{3} \mathrm{HT}$ film. Upon annealing at $80{ }^{\circ} \mathrm{C}$, the morphology of the $\mathrm{ZnO} / \mathrm{P}_{3} \mathrm{HT}$ film changes and the $\mathrm{ZnO}$ nanostructures diffuse out of the polymer and are dispersed evenly in the $\mathrm{P}_{3} \mathrm{HT}$ matrix, as shown in Fig. 3g. It is observed from Fig. $3 \mathrm{~h}$ that larger $\mathrm{ZnO}$ structures with an average diameter of $450 \mathrm{~nm}$ (see inset, Fig. $3 \mathrm{~h}$ ) appear as the temperature reaches $140-160{ }^{\circ} \mathrm{C}$, and their amount increases dramatically at $160{ }^{\circ} \mathrm{C}$ due to softening of the $\mathrm{P}_{3} \mathrm{HT}$ chains, which allows the $\mathrm{ZnO}$ structures to move easily throughout the polymer matrix, resulting in an increase in surface roughness. This increase in sur- face roughness is considered to be a signal of polymer self-organisation and phase separation [15]. However, the surface morphology of the film changed completely after 
annealing at $220{ }^{\circ} \mathrm{C}$, showing cracks and "cone-like" structures across the film surface, as shown in Fig. 3i. The size distribution (see inset, Fig. 3i) indicated that the average particle size decrease from $450 \mathrm{~nm}$ to $400 \mathrm{~nm}$ due to a disordering of the $\mathrm{ZnO} / \mathrm{P}_{3} \mathrm{HT}$ film, induced by annealing.

To investigate the effect of annealing on the charge transfer between the polymer and acceptor materials, PL spectroscopy was employed; the spectra are shown in Fig. 4. The reduced $\mathrm{PL}$ intensity for the $\mathrm{ZnO} / \mathrm{P}_{3} \mathrm{HT}$ is induced by the formation of $\mathrm{ZnO}$ "cone-like" structures across the film, as shown in Fig. 3c. Upon annealing of the $\mathrm{ZnO} / \mathrm{P}_{3} \mathrm{HT}$ or the $\mathrm{ZnO} / \mathrm{P} 3 \mathrm{HT}$ :PCBM hybrid structure around $80-140{ }^{\circ} \mathrm{C}$, a partial recovery in the PL emission intensity is observed [35]. Annealing above the glass transition temperature ( $\mathrm{Tg}$ ) of the $\mathrm{P}_{3} \mathrm{HT}$ promoted phase separation be- tween $\mathrm{P}_{3} \mathrm{HT}, \mathrm{ZnO}$ and $\mathrm{PCBM}$, with higher temperatures resulting in an increased $\mathrm{P}_{3} \mathrm{HT}$ emission intensity because fewer excitons generated within the $\mathrm{P}_{3} \mathrm{HT}$ domains diffused to an interface with PCBM to undergo dissociation into free charges [35]. Upon annealing at elevated temper- atures $\left(160-220{ }^{\circ} \mathrm{C}\right)$, the PL intensity decreased. This reduction in the PL emission can be explained as follows: because the compatibility of the ZnO-nanorods/ $\mathrm{P}_{3} \mathrm{HT}$ (or ZnOnanorods/ $\mathrm{P}_{3} \mathrm{HT}: \mathrm{PCBM}$ ) with the $\mathrm{P}_{3} \mathrm{HT}$ sur- face improved, the elongation of the $\mathrm{P}_{3} \mathrm{HT}$ chains was hindered by the el- evated temperature anneal. This reduced chain elongation decreased the conjugated chain length of the $\mathrm{P}_{3} \mathrm{HT}$ and formed new segments because of the scission of the $\mathrm{P}_{3} \mathrm{HT}$ chains and the formation of amorphous $\mathrm{P}_{3} \mathrm{HT}$ domains (Fig. 3a) induced by thermal stress and degradation.
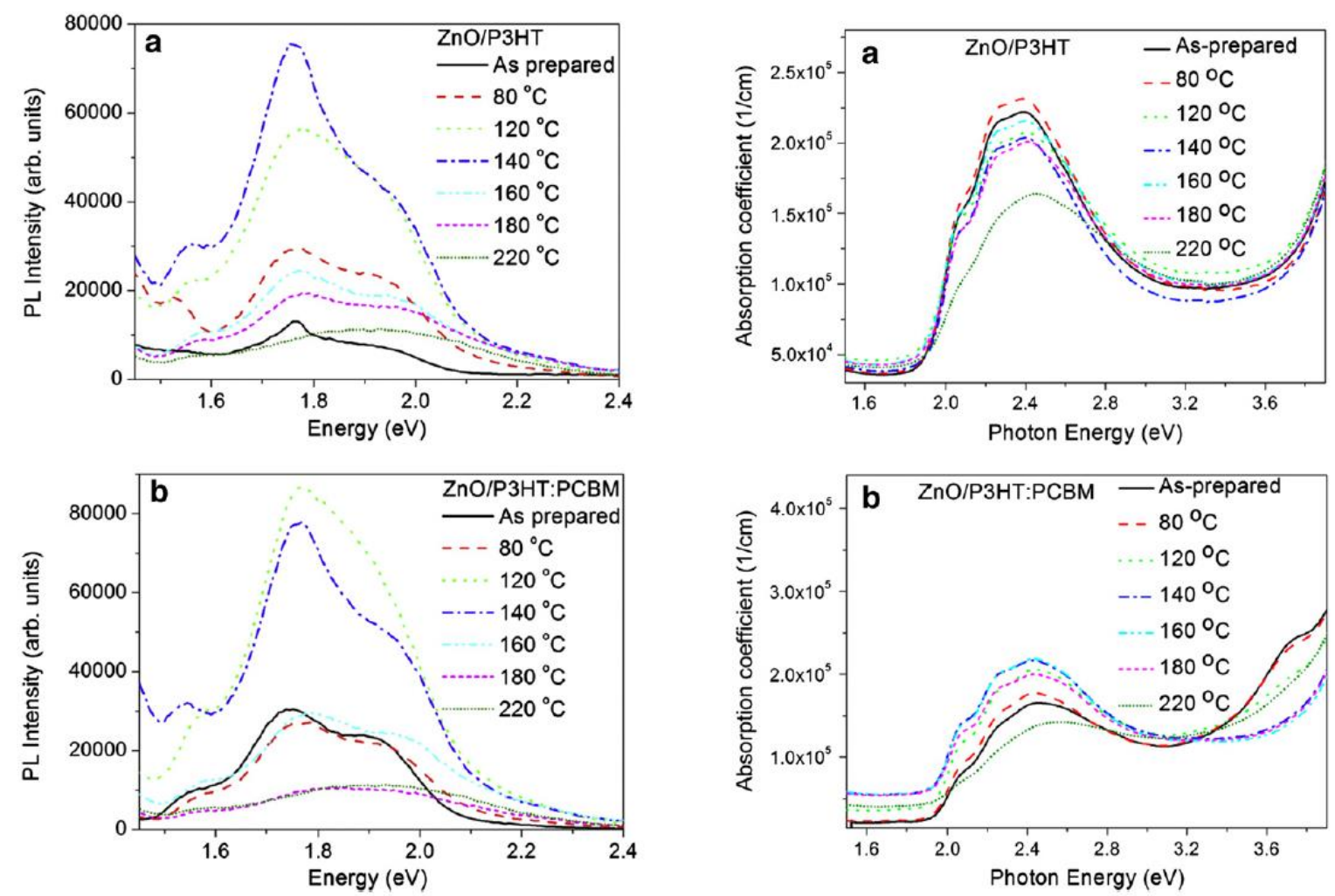

Fig. 4. PL spectra of the as-prepared (a) ZnO/P3HT and (b) ZnO/P3HT:PCBM hybrid structures compared to those annealed at temperatures ranging from 80 to $220^{\circ} \mathrm{C}$ for $15 \mathrm{~min}$, with an increment of $20^{\circ} \mathrm{C}$.

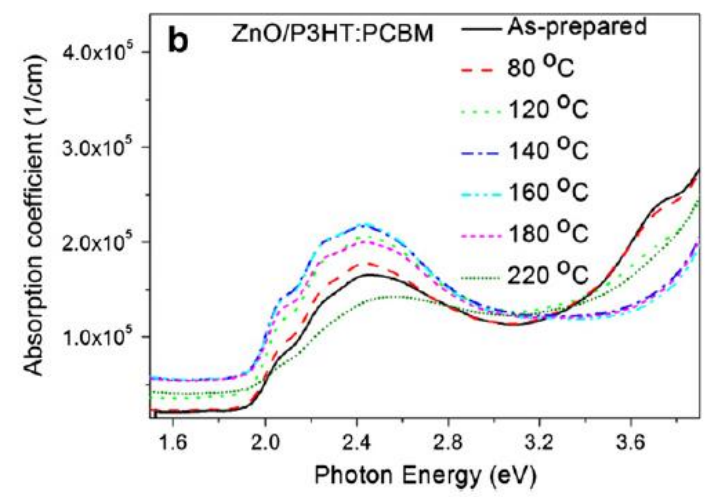

Fig. 5. UV-vis absorption spectra of the as-prepared and annealed (a) $\mathrm{ZnO} / \mathrm{P3} \mathrm{HT}$ and (b) ZnO/P3HT:PCBM hybrid structures at temperatures ranging from 80 to $220^{\circ} \mathrm{C}$ for $15 \mathrm{~min}$, with an increment of $20^{\circ} \mathrm{C}$

Fig. 5 shows the absorption spectra of the as-prepared and annealed $\mathrm{ZnO} / \mathrm{P}_{3} \mathrm{HT}$ and $\mathrm{ZnO} / \mathrm{P}_{3} \mathrm{HT}$ :PCBM hybrid films. The $\mathrm{ZnO} / \mathrm{P}_{3} \mathrm{HT}$ exhibits a broad absorption spectrum 
ranging from 1.8 to $2.5 \mathrm{eV}$. From Fig. $5 \mathrm{a}$, it is clear that enhanced optical density of the absorption spectra below $3.2 \mathrm{eV}$ in the $\mathrm{ZnO} / \mathrm{P}_{3} \mathrm{HT}$ hybrid, which mainly results from the contribu- tions of $\mathrm{ZnO}$-nanorods, cannot be observed. The $\mathrm{ZnO} / \mathrm{P}_{3} \mathrm{HT}$ and $\mathrm{ZnO} / \mathrm{P} 3 \mathrm{HT}: \mathrm{PCBM}$ films that were annealed at $80-160{ }^{\circ} \mathrm{C}$ exhibited improved absorbance, and the shoulders at 2.24 and $2.06 \mathrm{eV}$ became more discern- ible and were correlated with the degree of crystallinity of the $\mathrm{P}_{3} \mathrm{HT}$ films, as demonstrated by the XRD data [36]. It was further observed that the band gap values of the $\mathrm{ZnO} / \mathrm{P}_{3} \mathrm{HT}$ :PCBM decreased from $1.93 \mathrm{eV}$ (for the as-prepared or RT) to $1.81 \mathrm{eV}$ (at $160{ }^{\circ} \mathrm{C}$ ), demonstrating that the op- timal annealing temperature for maximising light absorption properties is $160{ }^{\circ} \mathrm{C}$. Thermal annealing resulted in more delocalised conjugated $\pi$ electrons, lowering of the band gap between $\pi$ and $\pi^{*}$, and an increase of the optical $\pi-\pi^{*}$ transition, which resulted in the observed red shift in the peak photon energy.

Fig. 6a depicts the calculated pseudodielectric function (closed and open squares) of the as-prepared $\mathrm{ZnO} / \mathrm{P}_{3} \mathrm{HT}: \mathrm{PCBM}$ spectra on a $\mathrm{Si}$ sub- strate at 65,70 and $75^{\circ}$ angles of incidence (AOI) together with the data on $\Psi$ (solid lines) and $\Delta$ (dashed lines). The fit shows excellent agreement between the model calculation and the experimental data, confirming the quality of the fit and our SE analysis. Fig. 6b shows the ellipsometry spec- tra of $\mathrm{ZnO} / \mathrm{P}_{3} \mathrm{HT}: \mathrm{PCBM}$, taken in the form of $\Psi$ and $\Delta$ values at different temperature exposures. For clarity, we only show the $75^{\circ}$ AOI spectra be- cause the spectra behave similarly at different AOI (Fig. 6a). It is evident from Fig. 6b and c that the values of $\Psi$ and $\Delta$ at $2.05 \mathrm{eV}$ increase with annealing temperature. Because $\Psi$ is interpreted as a measure of the den- sity of the polymer film [37], we therefore suggest that the film density in- creases with annealing temperature, which is attributed to the polymer crystallisation, as depicted in the XRD and UV-vis results.

Fig. 7 shows the optical constants of the hybrid structures at various annealing temperatures. The peaks of the optical curves are red-shifted due to the enhanced intermolecular order from the flatter molecular con- formation and reduced torsion of $\mathrm{P}_{3} \mathrm{HT}$ after annealing. By increasing the temperature, the refractive index increases from 2.63 to 2.77 for the as-prepared and $120{ }^{\circ} \mathrm{C}$-annealed films, and a further decrease is noted between 160 and $220{ }^{\circ} \mathrm{C}$ due to degradation. The increased refractive index of films that are annealed at $120{ }^{\circ} \mathrm{C}$ is related to an increase in $\mathrm{P}_{3} \mathrm{HT}$ crystallisation, which subsequently increases inter-chain in- teractions [38]. The extinction coefficient peak at $2.4 \mathrm{eV}$ is enhanced from 0.27 to 0.39 for the asprepared and $160{ }^{\circ} \mathrm{C}$-annealed films. A larger extinction coefficient in the absorption band is caused by the crystallisation of the polymer material, which leads to further $\pi-$ $\pi^{*}$ absorption. The thermal annealing above the polymer's glass transition tem- perature gives the macromolecules the appropriate mobility to rearrange and achieve a more thermodynamically favourable demixed state. In the theoretical case of $t=\infty$, complete demixing is expected to occur, and the formation of a bilayer is thermodynamically possible [39]. 

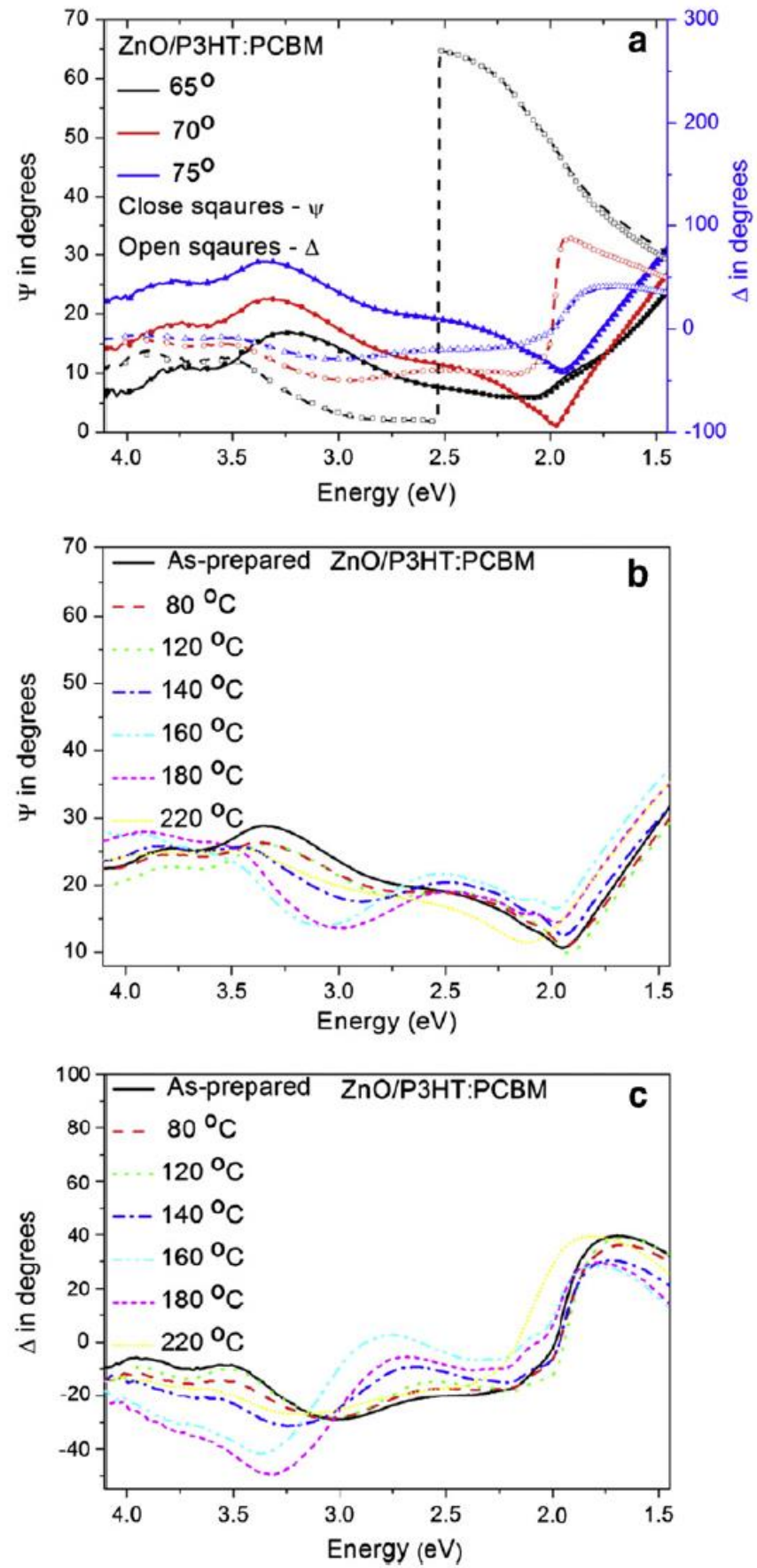

Fig. 6. Measured (a) $\Psi$ and $\Delta$ spectra (solid lines) with the model calculation (closed and open square) for $\mathrm{ZnO} / \mathrm{P3} \mathrm{HT}: \mathrm{PCBM}$ films at different angles of incidence, and (b) $\Psi$ and (c) $\Delta$ spectra measured at different temperatures $\left(80-220^{\circ} \mathrm{C}\right)\left(\mathrm{AOI}\right.$ is $\left.75^{\circ}\right)$. 

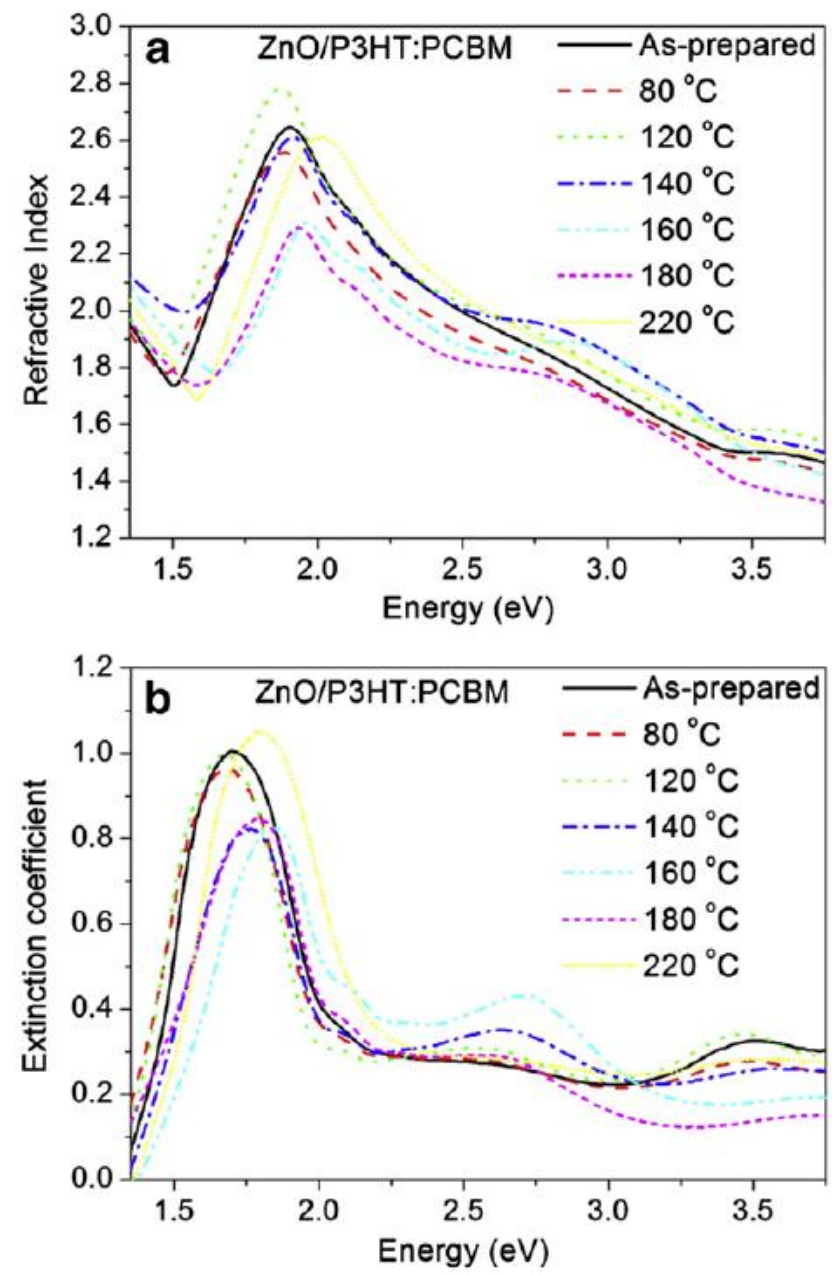

Fig. 7. Calculated (a) refractive index (n) and (b) extinction coefficient ( $k$ ) as a function of energy for $\mathrm{ZnO} / \mathrm{P3HT}$ :PCBM blends at temperatures ranging from 80 to $220^{\circ} \mathrm{C}$ 

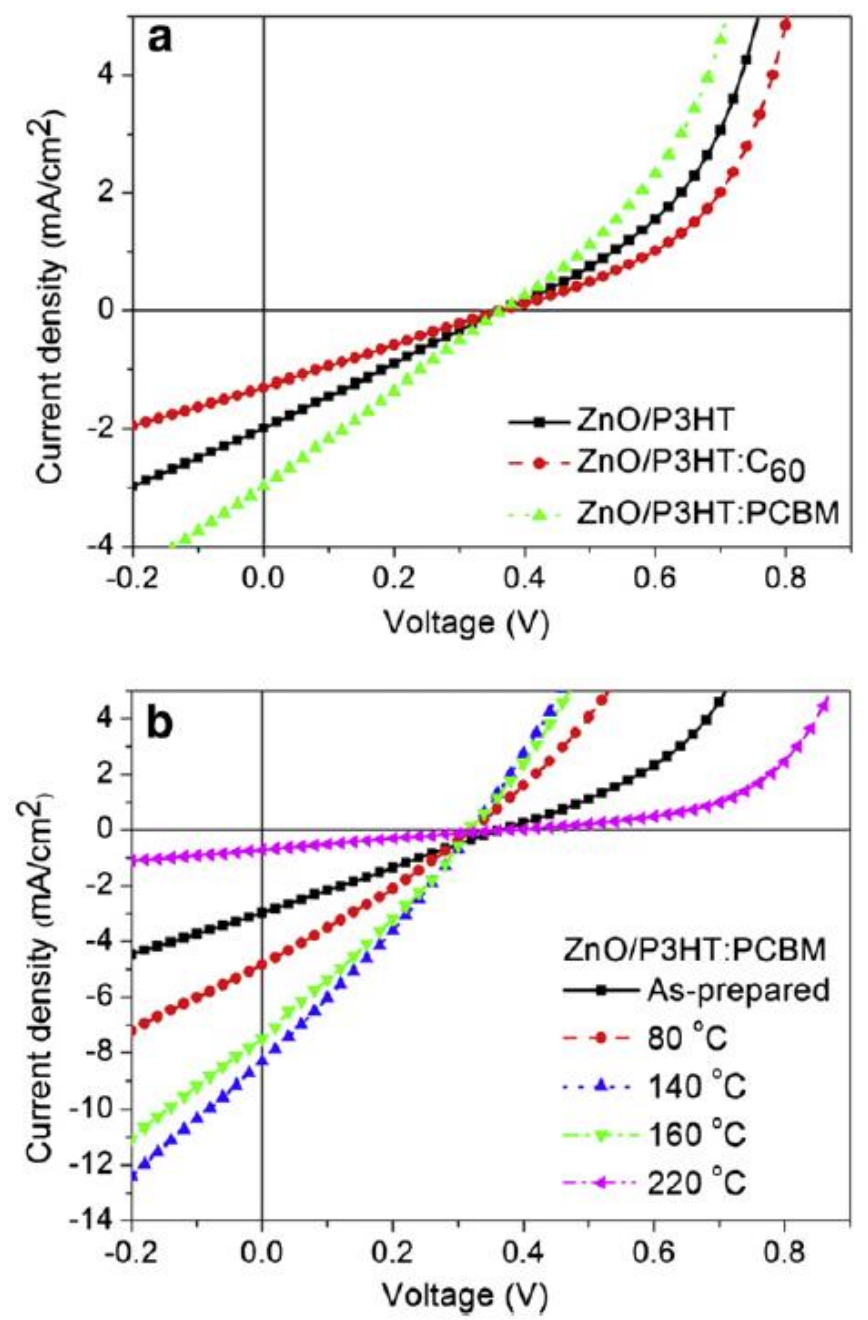

Fig. 8. Current density-voltage $\left(\mathrm{J}-\mathrm{V}\right.$ ) characteristics of the (a) $\mathrm{ZnO} / \mathrm{P} 3 \mathrm{HT}, \mathrm{ZnO} / \mathrm{P} 3 \mathrm{HT}: \mathrm{C}_{60}$ and (b) annealed $\mathrm{ZnO} / \mathrm{P3HT}: \mathrm{PCBM}$ at temperatures ranging from 80 to $220^{\circ} \mathrm{C}$, with an increment of $20^{\circ} \mathrm{C}$.

However, the value decreases to 0.29 at $220{ }^{\circ} \mathrm{C}$ due to the large PCBM aggregates formed and due to possible melting of the $\mathrm{P}_{3} \mathrm{HT}$ [35], as observed in Fig. 3a. Only minor changes in the strength of the PCBM absorption peaks around $3.6 \mathrm{eV}$ are observed with annealing temperature.

The current density-voltage $(\mathrm{J}-\mathrm{V})$ characteristics of the $\mathrm{P}_{3} \mathrm{HT}$ de- vices, combined with acceptor materials and annealed at different tem- peratures, are shown in Fig. 8 and Table 1. The photovoltaic properties were studied under AM $1.5 \mathrm{G}$ conditions with a light intensity of $100 \mathrm{~mW} / \mathrm{cm}^{2}$. The current density-voltage $(\mathrm{J}-\mathrm{V})$ characteristics are listed in Table 1. It is evident from Fig. 8a and Table 1 that the device based on the $\mathrm{ZnO} / \mathrm{P}_{3} \mathrm{HT}: \mathrm{PCBM}$ structure exhibits an improved short-circuit current density $\left(\mathrm{J}_{\mathrm{Sc}}\right)$ and fill factor $(\mathrm{FF})$, as well as a higher power conversion effi- ciency (PCE) of approximately $0.3 \%$.

To study the effect of temperature on the photovoltaic properties of $\mathrm{ZnO} / \mathrm{P}_{3} \mathrm{HT}: \mathrm{PCBM}$, the solar cells were annealed at various annealing tem- peratures, as shown in Fig. 8b. The statistical data for the annealed devices are shown in Fig. 9. 


\begin{tabular}{lllll}
\hline Device structures & $\mathrm{V}_{\mathrm{oc}}(\mathrm{V})$ & $\mathrm{J}_{\mathrm{sc}}\left(\mathrm{mA} / \mathrm{cm}^{2}\right)$ & $\mathrm{FF}$ & $\mathrm{PCE}(\%)$ \\
\hline ZnO/P3HT & 0.36 & 2.01 & 0.25 & 0.20 \\
ZnO/P3HT:C 60 & 0.36 & 1.29 & 0.22 & 0.11 \\
ZnO/P3HT:PCBM & 0.35 & 3.11 & 0.25 & 0.30 \\
\hline
\end{tabular}

After annealing at $120{ }^{\circ} \mathrm{C}$, the $\mathrm{J}_{\mathrm{SC}}$ and $\mathrm{FF}$ increased, resulting in an estimated PCE of $0.46 \%$. A further increase in annealing temperature to $140{ }^{\circ} \mathrm{C}$ (Fig. 9a) induced a remarkable increase in the $\mathrm{J}_{\mathrm{Sc}}, \mathrm{FF}$ and PCE values. This result was attributed to the improved absorption of the incident light and the charge transportation properties of the highly ordered $\mathrm{P}_{3} \mathrm{HT}$ crystallites [40]. Liu et al. [41] showed that the PCEs of solar cells improve upon placing the cells in air for a few days due to the self-organisation of the $\mathrm{P}_{3} \mathrm{HT} / \mathrm{PCBM}$ layer and oxidation of the silver elec- trode with time, resulting in a significant enhancement of the $\mathrm{J}_{\mathrm{Sc}}, \mathrm{FF}$ and open circuit voltage $\left(V_{O c}\right)$. However, a decline in the $V_{\text {Oc }}$ was observed with annealing temperature, as shown in Fig. 9b. Guo et al. [42] reported that a decrease in the open circuit voltage may be due to a reduction in the work function of the Pt electrodes or due to the formation of shunts. When the annealing temperature increased from 160 to $220{ }^{\circ} \mathrm{C}$, the de- vices degraded, as depicted in the photovoltaic performances shown in Fig. 9. This degradation was induced by a degradation in the ordering of the $\mathrm{P}_{3} \mathrm{HT}$ films, resulting in the folding of the $\mathrm{ZnO} / \mathrm{P}_{3} \mathrm{HT}: \mathrm{PCBM}$ "skin layer" (Fig. 3a), the deficient PCBM molecules that accepted the generated electrons, and the deteriorated phase separation. Li et al. [43] and Malgas et al. [44] reported that a high annealing temperature $\left(180{ }^{\circ} \mathrm{C}\right)$ decreases the film roughness and reduces the solar cell efficiency.

\section{Conclusion}

The use of spectroscopic ellipsometry, UV-vis spectroscopy and XRD, combined with an examination of photovoltaic properties, enabled us to monitor the absorption, structural evolution and device performance of organic-inorganic hybrid structures with varying annealing tempera- tures. The ordering of $\mathrm{P}_{3} \mathrm{HT}$ nanocrystals increased during annealing, which also improved hole transport in the hybrid structures. Improved optical constants and absorption coefficients and a red shift of the band gap from 1.93 to $1.8 \mathrm{eV}$ were demonstrated for the annealed $\mathrm{ZnO} / \mathrm{P}_{3} \mathrm{HT}$ : PCBM films. 

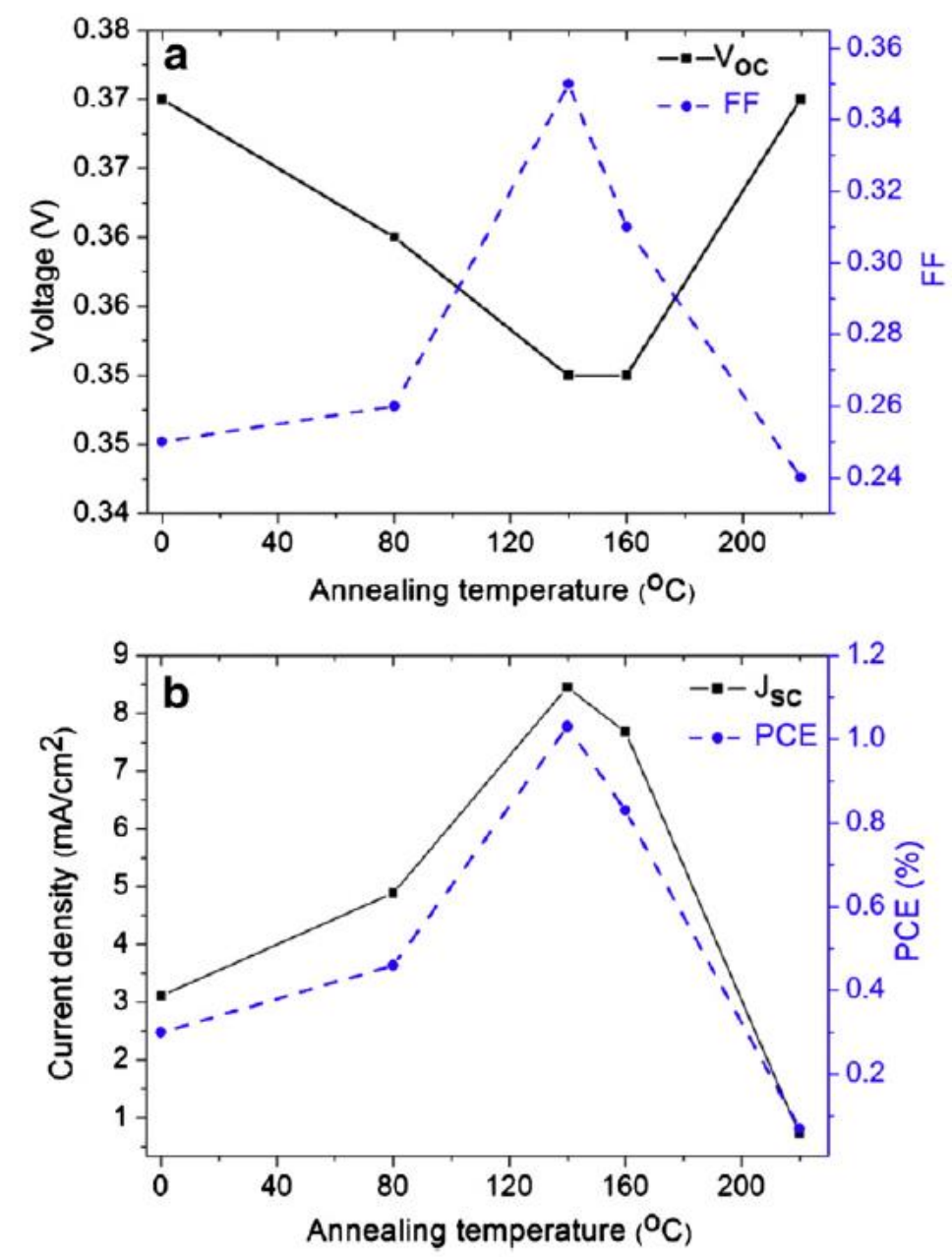

Fig. 9. Statistical data for the various annealed $\mathrm{ZnO} / \mathrm{P3HT}$ :PCBM devices (a) $\mathrm{J}_{\mathrm{sc}}$ and PCE and (b) $\mathrm{V}_{\mathrm{oc}}$ and FF. It should be noted that the films were annealed from 80 to $220{ }^{\circ} \mathrm{C}$ for $15 \mathrm{~min}$, with an increment of $20^{\circ} \mathrm{C}$.

These changes were explained in terms of the formation of $\mathrm{P}_{3} \mathrm{HT}$ crystallites upon annealing. Optimised photovoltaic performance for the solar cell device, which was based on a $\mathrm{ZnO} / \mathrm{P}_{3} \mathrm{HT}: \mathrm{PCBM}$ structure, was achieved at an annealed temperature of $140{ }^{\circ} \mathrm{C}$, with a maximum PCE of $1.03 \%$. Solar cell devices that were annealed at temperatures higher than 160 ${ }^{\circ} \mathrm{C}$ resulted in the degradation of the polymer and a reduction in the photovoltaic performance, as confirmed by the folding of the polymer "skin layer". These findings collectively suggest that, due to unsettled morphology, higher annealing temperatures cannot be used on $\mathrm{ZnO} /$ P3HT:fullerene solar cells to create devices with high efficiency and long term stability.

\section{Acknowledgements}

The authors are grateful for the financial support of the Department of Science and Technology and the Council for Scientific and Industrial Research (Project Nos.: HGER28P and HGER27S). 


\section{References}

[1] J.H. Burroughes, D.D.C. Bradley, A.R. Brown, R.H. Marks, K. Mackay, R.H. Friend, P.L. Burn, A.B. Holmes, Nature 347 (1990) 539.

[2] R.H. Friend, R.W. Gymer, A.B. Holmes, J.H. Burroughes, R.N. Marks, C. Taliani, D.D.C. Bradley, D.A. Dos Santos, J.L. Brédas, M. Lögdlund, W.R. Salaneck, Nature 397 (1999) 121.

[3] C.J. Brabec, V. Dyakonov, J. Parisi, N.S. Sariciftci, Organic Photovoltaics: Concepts and Realization, vol. 60, Springer, Berlin, 2003.

[4] T.R. Hebner, C.C. Wu, D. Marcy, M.H. Lu, C. Sturm, Appl. Phys. Lett. 72 (1998) 519.

[5] D.E. Motaung, G.F. Malgas, C.J. Arendse, Synth. Met. 160 (2010) 876.

[6] M.N. Yusli, T. Way Yun, K. Sulaiman, Mater. Lett. 63 (2009) 2691.

[7] W.L. Ma, C.Y. Yang, X. Gong, K. Lee, A.J. Heeger, Adv. Funct. Mater. 15 (2005) 1617.

[8] J.W. Kingsley, A. Green, D.G. Lidzey, Proc. SPIE Int. Soc. Opt. Eng. 7416 (2009) 74160T.

[9] F. Padinger, R.S. Rittberger, N.S. Sariciftci, Adv. Funct. Mater. 13 (2003) 85.

[10] P. Boland, S.S. Sunkavalli, S. Chennuri, K. Foe, T. Abdel-Fattah, G. Namkoong, Thin Solid Films 518 (2010) 1728.

[11] Y. Kim, S.A. Choulis, J. Nelson, D.D.C. Bradley, S. Cook, J.R. Durrant, J. Mater. Sci. 40 (2005) 1371.

[12] W.H. Lee, S.Y. Chuang, H.L. Chen, W.F. Su, C.H. Lin, Thin Solid Films 518 (2010) 7450. [13] G. Li, V. Shrotriya, J.S. Huang, Y. Yao, T. Moriarty, K. Emery, Y. Yang, Nat. Mater. 4 (2005) 864.

[14] G. Li, Y. Yao, H. Yang, V. Shrotriya, G. Yang, Y. Yang, Adv. Funct. Mater. 17 (2007) 1636.

[15] D.E. Motaung, G.F. Malgas, C.J. Arendse, T. Malwela, Mater. Chem. Phys. 124 (2010) 208.

[16] J.K. Lee, L. Wan, C.J. Ma, J. Brabec, J.S. Yuen, J.Y. Moon, K. Kim, G.C. Lee, A.J. Bazan, A.J. Heeger, J. Am. Chem. Soc. 130 (2008) 3619.

[17] L.-M. Chen, Z. Hong, G. Li, Y. Yang, Adv. Mater. 21 (2009) 1434.

[18] Y.Y. Yu, W.C. Chien, Y.H. Ko, S.H. Chen, Thin Solid Films 520 (2011) 1503.

[19] J. Bandara, K. Shankar, C.A. Grimes, M. Thelakkat, Thin Solid Films 520 (2011) 582.

[20] L.J.A. Koster, W.J.V. Strien, W.J.E. Beek, P.W.M. Blom, Adv. Funct. Mater. 17 (2007) 1297. [21] D.C. Olson, J. Piris, R.T. Collins, S.E. Shaheen, D.S. Ginley, Thin Solid Films 496 (2006) 26. [22] F. Li, Y. Du, Y. Chen, Thin Solid Films 526 (2012) 120.

[23] N.O.V. Plank, M.E. Welland, J.L. MacManus-Driscoll, L. Schmidt-Mende, Thin Solid Films 91 (2008) 7218.

[24] N. Kudo, Y. Shimazaki, H. Ohkita, M. Ohoka, S. Ito, Sol. Energy Mater. Sol. Cells 91 (2007) 1243.

[25] J.A. Woollam Co., Inc., Complete Ease ${ }^{\mathrm{TM}}$ Data Analysis Manual, 2008. [26] B. Johs, J.S. Hale, Phys. Status Solidi A 205 (2008) 715.

[27] M. Nakamura, C. Yang, K. Tajima, K. Hashimoto, Sol. Energy Mater. Sol. Cells 93 (2009) 1681.

[28] A. Phuruangrat, T. Thongtem, S. Thongtem, Mater. Lett. 63 (2009) 1224. [29] H. Li, E.T. Liu, F.Y.F. Chan, Z. Lu, R. Chen, Mater. Lett. 65 (2011) 3440.

[30] D.E. Motaung, G.F. Malgas, C.J. Arendse, S.E. Mavundla, Mater. Chem. Phys. 135 (2012) 401.

[31] P. Rai, H.-M. Song, Y.-S. Kim, M.-K. Song, P.-R. Oh, J.-M. Yoon, Y.-T. Yu, Mater. Lett. 68 (2012) 90. 
[32] D. Cullity, Elements of X-ray Diffraction, Addison-Wesley, 363 Reading, MA, 1956.

[33] P. Vanlaeke, G. Vanhoyland, T. Aernouts, D. Cheyns, C. Deibel, J. Manca, P. Heremans, J. Poortmans, Thin Solid Films 511-512 (2006) 358.

[34] D.E. Motaung, G.F. Malgas, C.J. Arendse, J. Mater. Sci. 45 (2010) 3276.

[35] D.E. Motaung, G.F. Malgas, C.J. Arendse, S.E. Mavundla, C.J. Oliphant, D. Knoesen, Sol. Energy Mater. Sol. Cells 93 (2009) 1674.

[36] T. Erb, U. Zhokhavets, H. Hoppe, G. Gobsch, M. Al-Ibrahim, O. Ambacher, Thin Solid Films 511-512 (2006) 483.

[37] M. Campoy-Quiles, G. Heliotis, R.D. Xia, M. Ariu, M. Pintani, P. Etchegoin, D.D.C. Bradley, Adv. Funct. Mater. 15 (2005) 925.

[38] T. Agostinelli, S. Lilliu, J.G. Labram, M. Campoy-Quiles, M. Hampton, E. Pires, J. Rawle, O. Bikondoa, D.D.C. Bradley, T.D. Anthopoulos, J. Nelson, J.E. Macdonald, Adv. Funct. Mater. 21 (2011) 170.

[39] J. Klein, T. Kerle, F. Zink, E. Eiser, Macromolecules 33 (2000) 1298.

[40] M.T. Khan, R. Bhargav, A. Kaur, S.K. Dhawan, S. Chand, Thin Solid Films 519 (2010) 1007.

[41] M.-Y. Liu, C.-H. Chang, C.-H. Chang, K.-H. Tsai, J.-S. Huang, C.-Y. Chou, I.-J. Wang, P.S. Wang, C.-Y. Lee, C.-H. Chao, C.-L. Yeh, C.-I. Wu, C.-F. Lin, Thin Solid Films 518 (2010) 4964.

[42] Y. Guo, H. Geng, Thin Solid Films 519 (2011) 2349.

[43] G. Li, V. Shrotriya, Y. Yao, Y. Yang, J. Appl. Phys. 98 (2005) 043704.

[44] G.F. Malgas, D.E. Motaung, C.J. Arendse, J. Mater. Sci. 47 (2012) 4282. 